\title{
Smallholder Farmers' Perception on Ecological Impacts of Agroforestry: Evidence from Northern Irrigated Plain, Pakistan
}

\author{
Shahzad Ahmad ${ }^{1}$, Caihong Zhang1*, E.M.B.P. Ekanayake ${ }^{1,2}$ \\ 'School of Economics and Management, Beijing Forestry University, Beijing 100083, China \\ ${ }^{2}$ Department of Forest Conservation, Sampathpaya, P.O.Box 3, Battaramulla, Sri Lanka
}

Received: 20 September 2020

Accepted: 10 November 2020

\begin{abstract}
Agroforestry (AF), a traditional land management system in Pakistan that provides great potential both to boost agriculture and reduce wood shortages. Previous work has identified many complex factors of AF covering socio-economic, and environmental impacts. Comparatively few have addressed the perception of the impact of AF. This study investigates the farmer perception of ecological impact derived from AF and the factors that influence their perception. The questionnaire was completed by 200 farmers in Northern irrigated plain in Pakistan, and the resulting descriptive statistics and a probit regression analysis were used to analyze the data. The results show that majority of farmers were believed AF increases the greenery, understory regeneration, water retention, and soil fertility of the farmland. In addition, the analysis shows that farmers' perceptions of AF were positively correlated with the native trees selected for cultivation. However, farmers who practice agrosilvopastoral system had less knowledge and perception of the ecological benefits of AF. Moreover, the study found, even though farmers plant exotic species they perceived that it had a negative impact on the water level and soil fertility. On the other hand, lack of technical knowledge also affected their perceived status. Therefore, designing and implementing informal education programs that collaborate with AF farmers and officials is suggested.
\end{abstract}

Keywords: agroforestry, ecological impact, farmer perception, northern irrigated plain, Pakistan

\section{Introduction}

For Pakistan, as a developing country, agriculture is considered the backbone of the economy. Approximately, $63.6 \%$ of Rural Pakistanis are directly or indirectly related to the agriculture sector. The share

*e-mail: zhangcaihong@263.net of agriculture to GDP is $18.5 \%$ and of total $42.3 \%$ are employed in this sector. However, agriculture sector is hit hard by many ecological factors such as land degradation, climate change and water scarcity [1]. When crops fail, majority of rural people rely on forest resources for their livelihoods and most of them use trees on farms to generate food and cash. Moreover, many countries in the developing world including Pakistan draw on fuel wood to meet as much as $90 \%$ 
of energy requirements [2]. Over the past decades, there has been a major decline in forest resources of Pakistan as a result of deforestation for agriculture and fuel wood [3].

Hence, ecological economists have made serious concern for the future of forest conservation, sustainable agricultural production, shortages of water and energy and adaptation to climate change $[4,5]$. In this respect, it demands maximum utilization of agricultural lands by adopting tree farming to improve rural livelihood as well as natural ecosystem [6]. To undertake this issue, the agroforestry system is one solution to increase forest resources by sustainable use of farm land by integrating crops, trees, and livestock. AF is a collective name of adoptability, productivity and sustainability of crops, trees and animals to create economic, environmental and social benefits [7]. The AF system consists of a substantive character of the complex structure of mixed trees and crops or livestock are raise together on the same land management unit [8].

Previous studies have covered wide range of socio, economic and environmental impacts of AF [9, 10]. Providing timber firewood, solid wood, wood pulp or biofuel for personal use on farm or selling are some of the economic benefits of AF [11]. Sustaining rural livelihoods by improving the resilience and amenity of local environments are major social benefits of AF $[12,13]$. It has been proved through many studies that AF practices provide a wide range of environmental services such as improve land reclamation, increase soil fertility, conserve biodiversity and water management $[10,14,15]$. Moreover, trees on farms provide shade and favorable environment to understory crops thus protecting from heat stress and fast winds [16]. Also, several other studies addressed the adoption of farmland trees and household-level variables that explain the adoption of AF practices [17, 18].

However, little importance has been given to perception on impact of AF. So, research needs to go beyond ranked lists to explore how AF influences individual decisions. Thus, the future success of AF in Pakistan will largely depend on assessing and addressing farmers' perceptions. To the best of our knowledge, no perceptional based study on AF is reported in northern irrigated plain of Pakistan where our study is conducted. Most of the farmers in study area are small holder farmers having a lower yield of wheat and rice because of poor management practices. Hence they are planting trees on cropland to increase production to improve their livelihood [19] and viewed it as environmentally friendly [20]. Trees in AF systems impact their surrounding environment and their impact doesn't be only a positive one. In some cases, they can provide habitat to the pests of crops or be an invasive species [21]. However, AF practices of farming communities are investigated in different economies found that mostly farmers have positive perceptions regarding impacts $[22,23]$. Insights about the above fact, our study puts forward research hypotheses as farmers will have a positive perception of the ecological impact of AF. Investigates the farmer perception on ecological impact derived from AF will be helpful in designing the effective projects to stimulate the country's economy by strengthening the AF sector in order to fulfill the gap between the supply of and demand for timber and fuel wood, thereby supporting to the enhancement of farm households' standard of living and eventually rural development.

Farmers' more positive beliefs with respect to integration of trees with crops are highly influenced by level of education, experience, farm land conditions and opinion and attitude of the farmers [24]. This study was conducted in Northern irrigated plain of Pakistan to examine socio-demographic factors that influence farmers' perception to adopt the AF system on their farms. Here, we addresses three issues: (1) what are the socio demographic characteristics of existing smallholder AF farmers? (2) Investigate the farmers' perception on ecological impacts of AF (3) identify the factors that affect farmers' perception on ecological impacts of AF. The results of this study will help to identify most dominant socio demographic and farm factors which influence farmers' perception and help policymakers set up appropriate policies and management strategies regarding AF.

\section{Methods and Data}

\section{Conceptual Framework}

There is a wide range of literature with respect to theories about perception. The cognitive dissonance theory of Festinger's predicts that the person having two thoughts that contradict each other (e.g. accept or reject/ yes or no) [25]. The existence of dissonance causes the individual to be psychologically uncomfortable, which then allows the individual to try to remain constant in thoughts. Perception is complex nonlinear process, influenced by multiple factors. Therefore, the use of a single theory in analyzing perception could not provide a full picture of the impacts [26]. A comprehensive framework that describes the interaction of various factors in perception is needed. In our study, we used an analytical framework that encompasses both socio demographic and farm factors that influence perception on the ecological impacts of AF (Fig. 1).

We developed this framework to show that farmers' perception of the ecological impacts of AF under the three themes (soil, water, plant, and animal) resulted from mental processes at the individual level and are shaped by socio-demographic and farm factors. All over the world, many studies revealed that sociodemographic and farm factors significantly affect the perceptions of the respondents [27, 28, 13]. Therefore, socio-demographic factors including age, level of education and farming experience; as well, farm factors such as the origin of the tree species, the type 


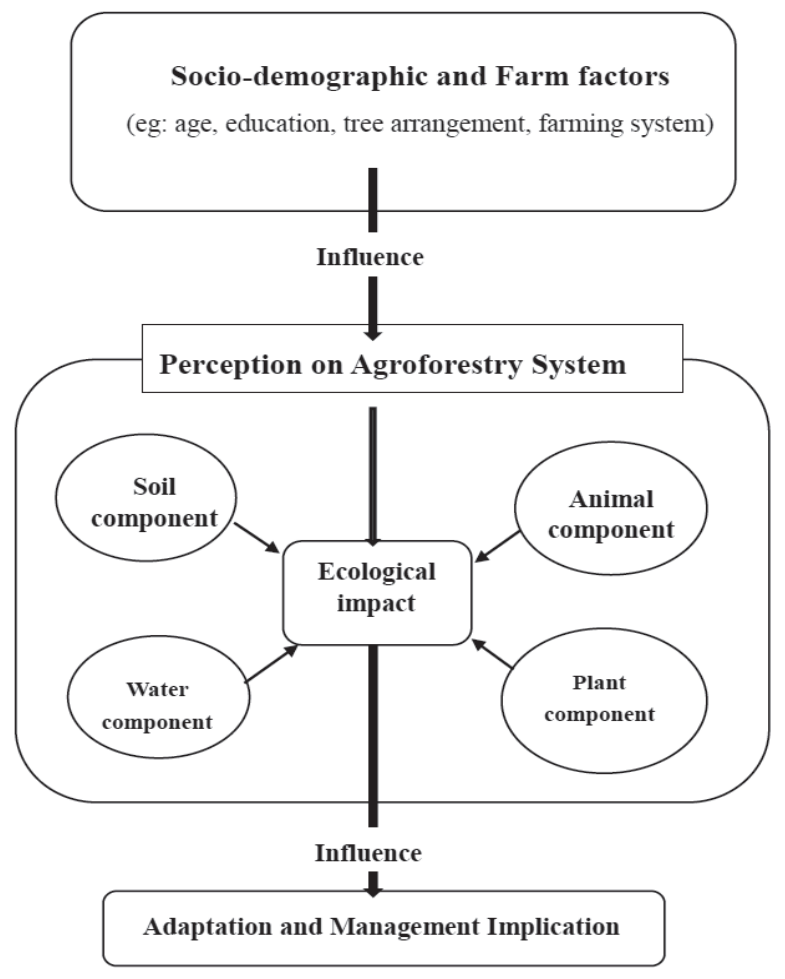

Fig. 1. A conceptual framework of individuals' perceptions of ecological impact of AF.

of AF system and arrangement of tree planting were incorporated into the framework.

\section{Study Area}

Pakistan is divided into ten agro-climatic zones based on soil type, climate, physiography, water availability and agricultural land use [29]. The research was carried out in two locations of the Northern irrigated plain (Zone IV-A). This Northern irrigated plain falls in
Punjab province and it is the second biggest province of Pakistan with an area of $205,344 \mathrm{~km}^{2}$, followed by stand first in population of 104.3 million. Punjab have 36 districts out of which 2 districts Gujranwala and Hafizabad were selected purposefully to represent sociodemographic and geographical variation. These districts were selected because they lying between Sutlej and Jhelum rivers among one of world largest canal system and majority of people depend on agriculture as their main income generation activity.

Geographically, locations of district Gujranwala is $32^{\circ} 9^{\prime} 24^{\prime \prime} \mathrm{N}$ to $74^{\circ} 11^{\prime} 24^{\prime \prime} \mathrm{E}$ and Hafizabad is $32^{\circ} 4^{\prime} 0$ "' North, $73^{\circ} 41^{\prime} 0^{\prime \prime}$ East. The Gujranwala district cover an area of $3,622 \mathrm{~km}^{2}$ with a populations of 5,014,196 and households are 747,214, while Hafizabad district cover an area of 2,367 $\mathrm{km}^{2}$ with a population of 1,156,957 and 175,180 households. Tehsil Kamoke, Tehsil Noshera Virkan, Tehsil Wazirabad and Tehsil Pindi bhattia was further selected for research from these two districts (Fig. 2). The region climate is semi-arid to sub-humid with the mean maximum monthly temperature rises up $45^{\circ} \mathrm{C}$ in summer and mean minimum temperature drop to $6^{\circ} \mathrm{C}$ in winter season. The region annual average rainfall is $300-500 \mathrm{~mm}$ in north part and 200 to $300 \mathrm{~mm}$ in the south part. The land soil is sandy loam to clayey loam with a weak structure, thus it is considered as most important part for country for agricultural activity. Different types of crops wheat, millet, rice and sugarcane are produce on the north part of the region and on the center-south part farmers prefer to grow wheat, cotton, maize, mangoes through canal irrigation system. Northern irrigated plain have a high potential of supporting AF system as in this region mostly farmer plants Tamarix aphylla, Acacia modesta, Acacia nilotica, Prosopis cineraria and Zizyphus spp. and Dalbergia sissoo (Sheesham) trees on the boundaries of agricultural fields as shelter belts to protect crops from fast winds and soil erosion, in addition to utilized for fodder and fuel wood $[30,31]$.

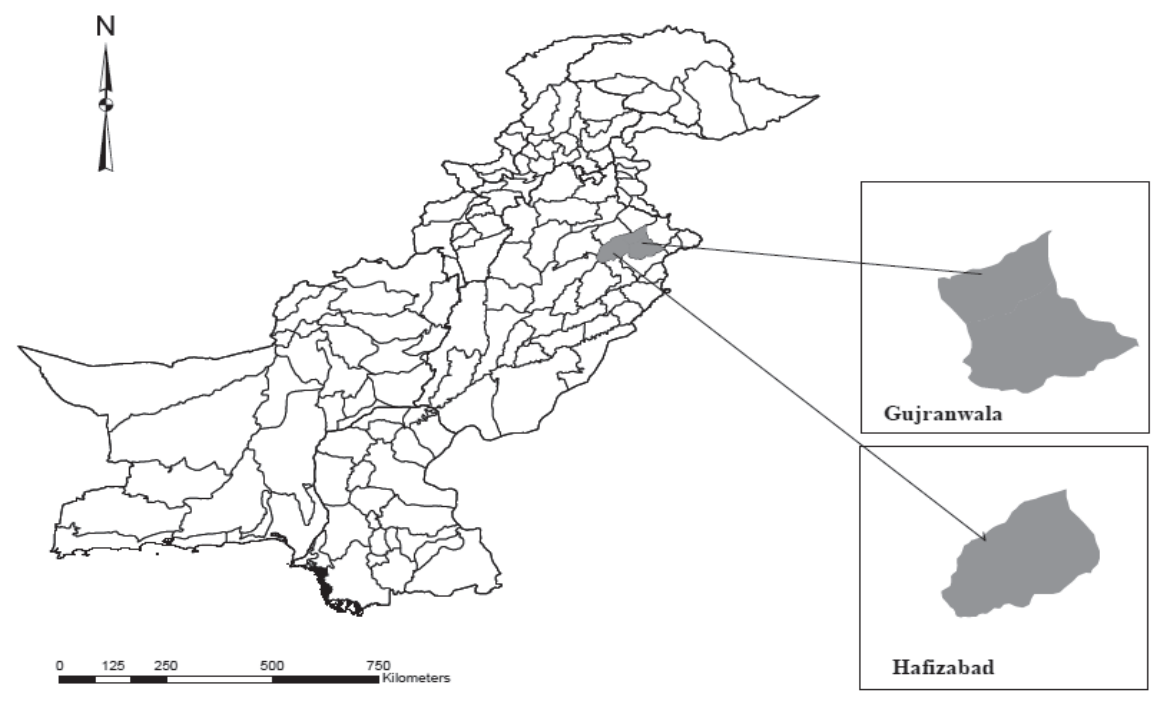

Fig. 2. Location of selected study site of District Gujranwala and District Hafizabad in Pakistan. 


\section{Data Collection and Analysis}

During data collection, 20 villages were randomly selected out of 4 Tehsils across the two Districts. In these 20 villages, lists of all households were collected from the Tehsil. Office. With the help of village headmen (lumberdar), the households which are not involved in $\mathrm{AF}$ farming were excluded from the list. Then, we selected every second household from the name list of farmers collected from each village and obtained ten individual farmer from each village. Totally 200 individuals were selected to participate in the survey. To analyse the farmers' perceptions on ecological impact of $\mathrm{AF}$, household surveys were conducted. Data was collected through household face to face interviews using semi-structured questionnaires.

The main component of the ecosystem are biotic components include plants, animals, decomposers and non-living components include air, water, land [32, 33]. Several studies used these components to analyse ecological impacts [34-36]. Following the previous literature, farmer's perception towards the ecological impact of AF was collected by using ten statements based on 4 variables namely (1) soil, (2) water, (3) plant (4) animal. Each variable is evaluated using different indicators. Following several studies conducted in different parts of the world, soil variable measures by soil erosion, soil structure, and soil fertility; water variable measures using indicators namely water retention and water volume of tube wells; plant variable measures using microclimate, greenery, and understory vegetation; and animal variable measures using indicators of pollination, soil macro fauna, and insect pest [37, 38, 23]. Each indicator were measured using three point scale and rated using 1-3. In scale, ' 1 ' represents decreased than before ' 2 ' represents the same as before and ' 3 ' represents increased than before is used to assess a particular indicator.

Following the previous literature on AF [39-41], the questionnaire also collected information on five socio-demographic characteristics of the participants: age, level of education, the experience of doing AF, types of AF, the origin of AF trees and arrangement of tree planting. To identify potential links between those socio-demographic characteristics and individuals' knowledge and perceptions of ecosystem benefits of AF, we implemented a probit regression analysis. The Probit regression system is well adapted to determining factors affecting participants' responses to binary choices [42].

Dependent variables related to their knowledge and perceptions were developed using eight questions reported in Table 1. We used participants' sociodemographic characteristics as independent variables (Table 2).

In the analysis, age and year of experience is measured in number of years. The variable for participants' education was constructed as a 5 scale variable taking a value of 1 for illiterate, 2 for primary, 3 for ordinary level, 4 for intermediate and value of 5 for advanced level. The AF system variable took a value of 1 for farmers engaged in the agrisilvicultural system, 2 for participants engaged in silvopastoral, and 3 for participants engaged in agrosilvopastoral system. The origin of tree species variable was formulated as a dummy variable in which exotic species took a value of 0 and native species took a value of 1 . Similarly, arrangement of tree planting variable also formulated as dummy in which 0 is used for composite planting and 1 is used for boundary planting.

\section{Results and Discussion}

\section{Socio Demographic Characteristics}

The information about characteristics profile of the AF farmer are presented in Table 2. The average age of AF farmer was 42.38 with a minimum of 19 and maximum of 73 years of age. According to our result, majority of AF farmers were middle aged. Similarly study in Pakistan and in Kashmir, India reported that middle aged farmers are more willing to participate in AF $[43,23]$. However, study in Uttarakhand in India

Table 1. Responses to question regarding the ecological impact of AF.

\begin{tabular}{|c|c|c|}
\hline Questions & $\begin{array}{c}\text { Response } \\
(\text { Dummy; Yes =1, No }=0)\end{array}$ & Variable \\
\hline 1. Did AF improve soil condition & Yes/No & Soil \\
\hline 2. Did AF improve land greenery & Yes/No & Understory \\
\hline 3. Did AF improve understory regeneration & Yes/No & Water \\
\hline 4. Did AF improve ground water level & Yes/No & Air \\
\hline 5. Did AF improve air quality & Yes/No & Pest \\
\hline 6. Did AF control pest & Yes/No & Diversity \\
\hline 7. Did AF improve bio diversity & Yes/No & Pollination \\
\hline 8. Did AF improve pollination & Yes/No & \\
\hline
\end{tabular}


Table 2. Socio-Demographic Characteristics profile of the AF farmers.

\begin{tabular}{|c|c|c|c|c|c|c|c|}
\hline \multirow{2}{*}{ Variables } & \multirow{2}{*}{ Unit } & \multirow{2}{*}{$\begin{array}{c}\text { Range } \\
\text { Observed }\end{array}$} & \multirow{2}{*}{ Categories } & \multicolumn{2}{|c|}{ Respondents } & \multirow[t]{2}{*}{ Mean } & \multirow[t]{2}{*}{ SD } \\
\hline & & & & Number & Percent $\%$ & & \\
\hline \multirow{3}{*}{ Age } & \multirow{3}{*}{ Number of years } & \multirow{3}{*}{$19-73$} & Young $(\leq 30)$ & 39 & 19.5 & 42.38 & 11.82 \\
\hline & & & Middle age (31-50) & 109 & 54.5 & & \\
\hline & & & Old $(>50)$ & 52 & 26 & & \\
\hline \multirow{5}{*}{ Education } & \multirow{5}{*}{ Schooling years } & \multirow{5}{*}{$1-5$} & Illiterate & 9 & 4.5 & 3.22 & 0.97 \\
\hline & & & Primary (1-5) & 33 & 16.5 & & \\
\hline & & & Ordinary level (6-10) & 80 & 40 & & \\
\hline & & & Intermediate (11-12) & 61 & 30.5 & & \\
\hline & & & Advance level (>12) & 17 & 8.5 & & \\
\hline \multirow{3}{*}{ Experience } & \multirow{3}{*}{ Years of farming } & \multirow{3}{*}{$3-34$} & Less $(\leq 5)$ & 22 & 11 & 13.12 & 6.78 \\
\hline & & & Moderate (6-20) & 148 & 74 & & \\
\hline & & & More $(>20)$ & 30 & 15 & & \\
\hline \multirow{3}{*}{ AF system } & \multirow{3}{*}{ Type of farming } & \multirow{3}{*}{$1-3$} & Agrisilvicultural & 77 & 38.5 & & \\
\hline & & & Silvopastoral & 27 & 13.5 & & \\
\hline & & & Agrosilvopastoral & 96 & 48 & & \\
\hline \multirow{2}{*}{$\begin{array}{l}\text { Origin of tree } \\
\text { species }\end{array}$} & \multirow{2}{*}{ Origin } & \multirow{2}{*}{$0-1$} & Exotic & 111 & 55.5 & & \\
\hline & & & Native & 89 & 44.5 & & \\
\hline \multirow{2}{*}{$\begin{array}{l}\text { Arrangement of tree } \\
\text { planting }\end{array}$} & \multirow{2}{*}{ Structure } & \multirow{2}{*}{$0-1$} & Composite planting & 54 & 27 & & \\
\hline & & & Boundary planting & 146 & 73 & & \\
\hline
\end{tabular}

and Rwanda found major respondents who engage in AF were old - aged [44, 45].

The education level of farming community were $4.5 \%$ illiterate and $16.5 \%$ had primary education of 1-5 years. The highest education attained by the respondents are ordinary level education (6-10 years), they account $40 \%$ of the total, while $30 \%$ had education on intermediate level (11-12 years). About 8 $\%$ AF farmers reached university level or more than 13 years of education. Education has impacted the income generation activities of the rural people [46, 47]. Higher education opens up the opportunity to paid government and private jobs [48]. Hence majority of the villagers who had higher education (Intermediate or University) are less depend on the AF. Similarly, the study in southern Costa Rica and in India revealed that AF farmers had an average 10 year education $[49,50]$.

The results show $11 \%$ of the farmers had been practicing AF less for than 6 years, $74 \%$ farmers are practicing $\mathrm{AF}$ for 6-20 years and $15 \%$ farmer had experience of more than 20 years. The farmers had average experience of AF was 13.12 years with a minimum of 3 and a maximum of 34. Study by [31] noted that a number of AF farmlands in northern irrigated plain were considerably increased in the period of year 2000. It's in line with our study which indicate that majority of farmers had about 20 year experience in farming.

Based on the composition, stratification and dimension of the crops, many countries divided AF in to three main systems namely agrisilvicultural, silvopastoral and agrosilvopastoral. Our results indicated that, approximately $38 \%$ of farmers adopt agrisilvicultural practice on their farms and $22 \%$ farmer practicing silvopastoral AF, while nearly half of the sample respondent (48\%) practicing agrosilvopastoral system. Most part of the northern irrigated lands, either simultaneously or alternately farmers grow agriculture crops with forest trees. Triticum aestivum (wheat), Solanum tuberosum (potato), Zea mays (Maize), Saccharum officinarum (sugar cane), Brassica nigra (Mustard), Curcuma longa (turmeric) are common crops growing in AF field. Many studies found that silvopastoral and agrosilvopastoral systems can be used to increase livestock income [51-53]. Growing fodder trees and planting grasses and other feed plants between trees enhanced the productivity of the farmlands [54]. We found that, along with trees or conjunction with trees and agricultural crops, large herds of livestock (buffalo, cattle, goats, sheep, poultry and asses) are raised under the AF system. According to our findings, Buffalos (54\%) contribute the largest 
portion of livestock followed by cattle $(21 \%)$, poultry $(16 \%)$ goat $(6 \%)$ and other species $(2 \%)$.

During the study we found that farmers plant both native and exotic trees in their farmlands. Among the species, 19 were native trees and 9 were exotics. The result shows that majority of farmers' prefer to plant exotic species $(55.5 \%)$ on farm lands than native species trees $(44.5 \%)$. Most prevalent five exotic tree species is Populus deltoides followed by Prosopis juliflora, Eucalyptus camaldulensis. Swietenia mahagoni and Acacia auriculiformis. Five main dominant native species were Dalbergia sissoo, Vachellia nilotica, Acacia modesta, Mangifera indica, and Azadirachta indica. In addition, shrub species namely Sueda fruticosa, Morus macroura and grasses such as Eleusine flagellifera, Panicum cymbopogan and Lasiurus scindicus are common in the AF lands. Trees and shrubs in AF lands were mainly used as shade trees as well as boundary demarcation. In addition they are lopped for fuel wood fodder and some construction purposes (timber for rural house, woods for animal shelters). Among the native species, fruit trees (Psidium guajava, Mangifera indica) represented $32 \%$ of the species planted in AF lands of the study area which provide edible fruits and medicine. Grasses were common in agrosilvopastoral systems where buffalos and cattle managed.

Traditionally farmers plant different species of scattered trees in crop land [55]. Now a days boundary planting and composite planting (scattered and alley cropping) are common in many countries [56, 57]. Our study found that farmers in Northern irrigated plain in Pakistan are commonly practice boundary planting (73\%) than composite planting (27\%). Similar to our study, [57] revealed that boundary tree planting was most frequent strategy of the farmers living in Northern Bangladesh.

\section{Farmer's Perception on Ecological Impacts of AF}

Our respondents gave three kinds of responses regarding ecological impacts from AF under the 4 variables namely soil, water, plant and animal (Table 3, Fig. 3). Subsequently, a large portion of farmers felt that farm land greenery increased (81 \%) after introducing AF. Also, more than half of the respondent farmer believe that AF tress provide favorable environment $(51 \%)$ and increase of understory regeneration $(59.5 \%)$.

Growing different tree species in the unit area have increased the greenery of the AF lands. Therefore, no doubt farmers answered that greenery increases due to AF. However, the farmers of the study area regularly keep on lopping trees to maintain the required tree canopy opening and favorable environment for understory crops. Studies conducted in Mexico, Brazil, India and Ethiopia reported findings similar to our study [11, 16, 58-60].

Considering the soil variable, the $49 \%$ of respondents indicated that the soil erosion decreases as result of AF farming while soil fertility increases $(49.5 \%)$. However, respondents indicate that soil structure do not influence by the AF farming and $72 \%$ of farmers said it remain as before. The use of diverse tree species in different strata and other practices employed in AF leading to reduce the loss of soil and consequently increased the soil fertility [61]. Erosion is a major problem in tropical regions and is mainly caused by heavy rainfall on unprotected land. Several studies reported that AF can reduce erosion with up to 90 percent [10]. However, a contrast to our findings on soil structure, the study by [62] reported that more organic matter and the improved conditions for microorganisms and soil fauna in AF lands leads to improve the soil structure.

Table 3. Farmer's perception on ecological impacts of AF.

\begin{tabular}{|c|c|c|c|}
\hline \multirow{2}{*}{ Perception variables } & Decrease than before & Same as before & Increase than before \\
\cline { 2 - 4 } & $\%$ & $\%$ & 7.5 \\
\hline Soil erosion & 49 & 43.5 & 21.5 \\
\hline Soil structure & 6.5 & 47.5 & 49.5 \\
\hline Soil fertility & 3 & 46 & 23 \\
\hline $\begin{array}{c}\text { Favorable environment/micro } \\
\text { climate }\end{array}$ & 3 & 72.5 & 25.5 \\
\hline Pollination & 4.5 & 65.5 & 15.5 \\
\hline Soil macro fauna & 9 & 27 & 81 \\
\hline Insect pest & 57.5 & 18 & 59.5 \\
\hline Land greenery & 1 & 27 & 61 \\
\hline Understory regeneration & 13.5 & 28 & 21 \\
\hline Water retention & 11 & 61 & 27 \\
\hline Tube wells water level & 18 & $\%$ & \\
\hline
\end{tabular}




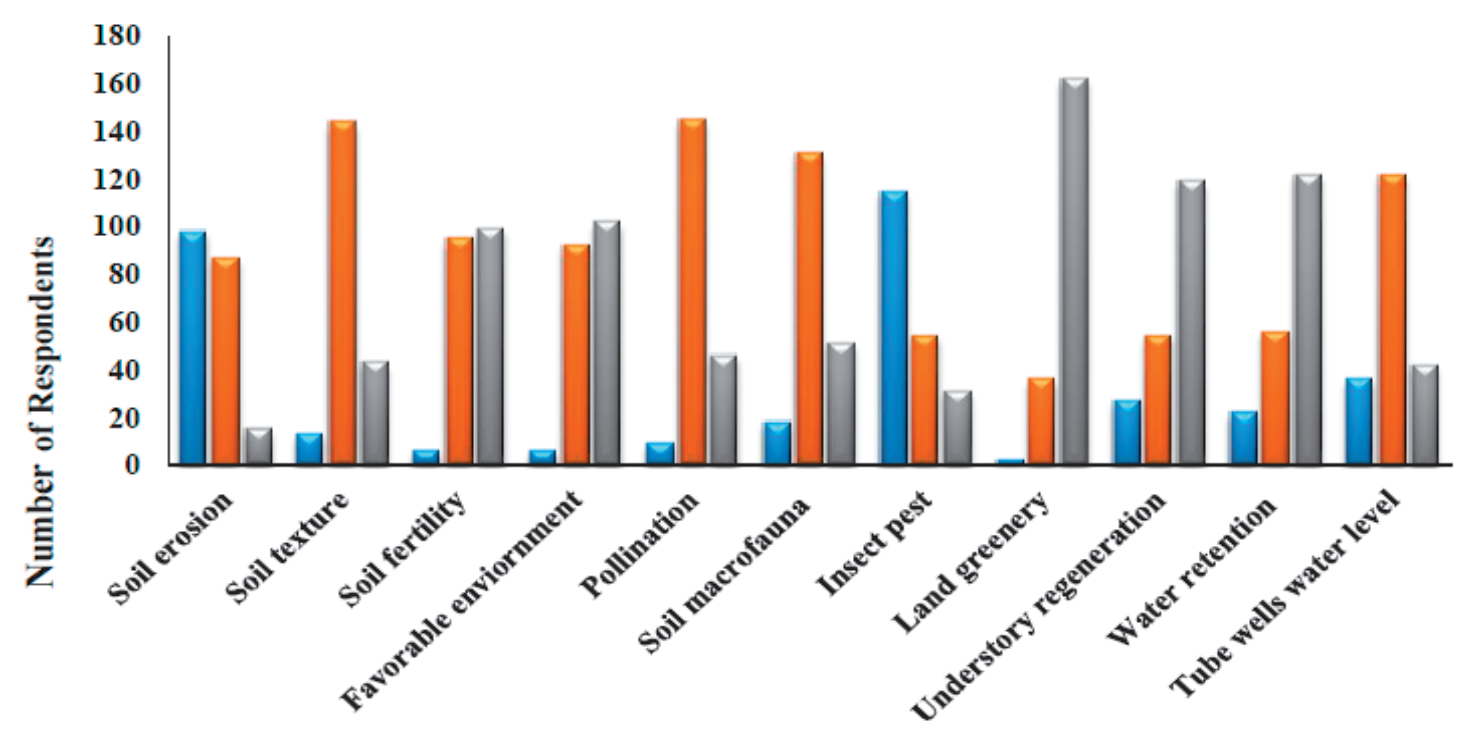

$\square$ Decrease than before (1) $\square$ Same as before (2) $\square$ Increase than before (3)

Fig. 3. Number of respondents' perception on ecological impacts of AF.

Considering the water variable, more than half $(61 \%)$ of the sample respondent indicated that water retention increase due to $\mathrm{AF}$ but on the other hand same proposition of farmers indicated that AF do not have influence on tube well water level. Soil and water are conserved through reducing soil loss from runoff and increasing of infiltration rate [63]. Research has shown that AF can help retain water; for example, some tree species grown on the upper levels of terraces have beneficial effects on soil water content in adjacent cropping areas [64, 65]. Ideally, groundwater should be available at a depth of 15-18 meters. However, during the last two decades, the groundwater level in the Northern irrigated plane has significantly dropped to 46-61 meters due to indiscriminate extraction. Therefore respondent perceived that even though AF shows promising results in improving water retention groundwater level do not increase [66, 67].

By increasing plant diversity in $\mathrm{AF}$, it is expected to increase beneficial arthropods and reduce pests [68]. However, about pollination, respondent perception more remains unchanged $(72.5 \%)$ and also they believe the amount of soil macro fauna in soil same as before $(65.5 \%)$ while $57.5 \%$ of respondent said that insect pest decreased after AF. Similar to our study, a meta-study conducted in Sweden, the UK, and Kenya have been shown that AF is beneficial in terms of pest, disease, and weed management [69].

\section{Factors Affecting Perceptions of the Respondents}

The results of the probit regression models are presented in Table 4. Of the three factors related to farmers' demographic characteristics, we found that age did not have a significant impact on their knowledge and perceptions. Similarly, several other studies conducted in different parts of the world found that age did not affect farmers' perception levels [70-72]. However, recent studies conducted in Indus River Basin of Pakistan and Bangladesh reported that younger farmers were more interested in the adoption of AF than old farmers as they are more knowledgeable about the benefit of applying advanced technology in farming such as $\mathrm{AF}[23,73]$.

Education level had a significant positive impact on farmerss' perception on soil $(\mathrm{P}<0.05)$ variable. Improvement of soil condition can measure in terms of soil fertility, soil structure as well as good aeration and bountiful microbial life [74]. Most of these conditions are invisible to the naked eye. Therefore uneducated peasant does not have the ability to describe whether AF improves soil condition or not. Farmers who have better education are satisfied with their knowledge of soil variables.

Furthermore, the results show that year of experience of participants has significant and positive correlation between perception of greenery and air variables at the $\mathrm{P}<0.01$ level. Studies found that over time AF improves land greenery and air quality $[75,10]$. Therefore more experienced farmers observed the improvement of these variables than less experienced ones. Also, they agreed with the statement of 'AF improve land greenery/ air quality'.

In terms of trees in farmland we find a significant and positive correlation between Origin of tree and their perception of benefit of AF (Understory, Water, Air Pest, Diversity and Pollination at the $\mathrm{P}<0.001$ level and Soil at the $\mathrm{P}<0.01$ level). The exception is greenery, for which there was positive correlated but insignificant. According to our result, we found that farmers believed growing native plants in AF system is more favorable for improving understory, water 
Table 4. Results of factors affecting to perceptions of the respondents.

\begin{tabular}{|c|c|c|c|c|c|c|c|c|}
\hline & Soil & Greenery & Understory & Water & Air & Pest & Diversity & Pollination \\
\hline Age & $\begin{array}{c}0.01 \\
(0.02)\end{array}$ & $\begin{array}{l}-0.04 \\
(0.02)\end{array}$ & $\begin{array}{c}0.01 \\
(0.01)\end{array}$ & $\begin{array}{c}0.01 \\
(0.02)\end{array}$ & $\begin{array}{c}0.00 \\
(0.01)\end{array}$ & $\begin{array}{l}-0.00 \\
(0.01)\end{array}$ & $\begin{array}{c}0.01 \\
(0.01)\end{array}$ & $\begin{array}{c}0.02 \\
(0.01)\end{array}$ \\
\hline Education & $\begin{array}{l}0.35^{*} \\
(0.17)\end{array}$ & $\begin{array}{c}0.32 \\
(0.20)\end{array}$ & $\begin{array}{c}0.14 \\
(0.12)\end{array}$ & $\begin{array}{c}0.26 \\
(0.14)\end{array}$ & $\begin{array}{c}0.12 \\
(0.14)\end{array}$ & $\begin{array}{c}0.83 \\
(0.12)\end{array}$ & $\begin{array}{c}0.24 \\
(0.13)\end{array}$ & $\begin{array}{c}0.25 \\
(0.13)\end{array}$ \\
\hline Year of experience & $\begin{array}{c}0.04 \\
(0.04)\end{array}$ & $\begin{array}{l}0.15 * * \\
(0.05)\end{array}$ & $\begin{array}{c}0.04 \\
(0.03)\end{array}$ & $\begin{array}{c}0.03 \\
(0.03)\end{array}$ & $\begin{array}{c}0.10^{* *} \\
(0.04)\end{array}$ & $\begin{array}{c}0.04 \\
(0.03)\end{array}$ & $\begin{array}{l}-0.02 \\
(0.03)\end{array}$ & $\begin{array}{l}-0.03 \\
(0.03)\end{array}$ \\
\hline Farming System & $\begin{array}{l}-0.33^{*} \\
(0.16)\end{array}$ & $\begin{array}{l}-0.10 \\
(0.17)\end{array}$ & $\begin{array}{c}-0.39 * * * \\
(0.11)\end{array}$ & $\begin{array}{c}0.23 \\
(0.14)\end{array}$ & $\begin{array}{l}-0.08 \\
(0.13)\end{array}$ & $\begin{array}{c}0.04 \\
(0.11)\end{array}$ & $\begin{array}{c}0.15 \\
(0.11)\end{array}$ & $\begin{array}{c}0.16 \\
(0.11)\end{array}$ \\
\hline Origin of tree & $\begin{array}{l}1.25^{* *} \\
(0.43)\end{array}$ & $\begin{array}{c}0.74 \\
(0.46)\end{array}$ & $\begin{array}{c}0.91 * * * \\
(0.23)\end{array}$ & $\begin{array}{c}2.54 * * * \\
(0.31)\end{array}$ & $\begin{array}{c}1.71 \text { *** } \\
(0.34)\end{array}$ & $\begin{array}{c}1.05^{* * *} \\
(0.23)\end{array}$ & $\begin{array}{c}1.36^{* * *} \\
(0.26)\end{array}$ & $\begin{array}{c}1.32 * * * \\
(0.28)\end{array}$ \\
\hline Arrangement of tree & $\begin{array}{l}-0.75 \\
(0.43)\end{array}$ & $\begin{array}{c}0.34 \\
(0.37)\end{array}$ & $\begin{array}{c}0.20 \\
(0.24)\end{array}$ & $\begin{array}{l}0.66^{*} \\
(0.31)\end{array}$ & $\begin{array}{l}-0.14 \\
(0.30)\end{array}$ & $\begin{array}{c}0.16 \\
(0.24)\end{array}$ & $\begin{array}{c}0.65 \\
(0.24)\end{array}$ & $\begin{array}{c}0.13 \\
(0.25)\end{array}$ \\
\hline Constant & $\begin{array}{l}-0.04 \\
(0.95)\end{array}$ & $\begin{array}{c}0.22 \\
(1.07)\end{array}$ & $\begin{array}{l}-0.80 \\
(0.72)\end{array}$ & $\begin{array}{c}-4.58 * * * \\
(0.99)\end{array}$ & $\begin{array}{l}-1.24 \\
(0.84)\end{array}$ & $\begin{array}{l}-0.56 \\
(0.72)\end{array}$ & $\begin{array}{l}-1.52 * \\
(0.77)\end{array}$ & $\begin{array}{l}-1.38 \\
(0.78)\end{array}$ \\
\hline \multicolumn{9}{|c|}{ Model features } \\
\hline LR chi2 & 40.84 & 21.07 & 50.50 & 143.56 & 87.90 & 39.98 & 45.25 & 37.53 \\
\hline Prob $>$ chi 2 & 0.0000 & 0.0018 & 0.0000 & 0.0000 & 0.0000 & 0.0000 & 0.0000 & 0.000 \\
\hline Pseudo R2 & 0.2642 & 0.3472 & 0.1980 & 0.5493 & 0.3677 & 0.1615 & 0.1879 & 0.1702 \\
\hline Log likelihood & -56.85 & -19.80 & -102.28 & -58.90 & -75.57 & -103.82 & -97.80 & -91.45 \\
\hline Number of observations & 200 & 200 & 200 & 200 & 200 & 200 & 200 & 200 \\
\hline
\end{tabular}

Legend: ${ }^{*} \mathrm{p}<.05 ;{ }^{* *} \mathrm{p}<.01 ; * * * \mathrm{p}<.001 /$ Numbers in parentheses are standard errors

and air quality, pollination, biodiversity as well as to control the pest. Also, they indicated that exotic trees utilize more water and cause water limitation to understory crops. Moreover, leaves of some exotic species (Eucalyptus spp) take a long time to decomposition and it reduces the growth of understory vegetation and plant diversity. Similarly study conducted in Hawaii found that exotic trees used water at a rate of more than twice that of native trees [76]. Also, some studies reported that negative competitive interactions for pollinator service may occur with the presence of exotic species and reduces the pollinator visitation to native species $[77,78]$.

Furthermore, the results show that Farming System has a significant negative correlation with Understory $(\mathrm{P}<0.001)$ and Soil $(\mathrm{P}<0.05)$ showing that farmers who have agrisilvicultural system more often feeling AF improve soil and understory than farmers with agrosilvopastoral system. Rearing farm animals under the trees caused a reduction of understory vegetation due to grazing. Moreover, farm animal hoof loosens the soil leads to soil erosion. On the other hand, we find the arrangement of tree has significant positive correlation between Water variable $(\mathrm{P}<0.05)$. Studies found that trees were more likely to use groundwater than shrubs [79]. Planting trees as scattered and alley cropping (composite planting) resulted in less water availability for cash crops (usually herbs or shrubs) growing under trees. Therefore, farmers who plant trees in boundary were satisfied that AF improve the ground water level compared to farmers who plant trees in composite manner.

With the recognition of a greater role of trees in farmland in global climate change, forest degradation debate, our result found that the AF practice in Pakistan and its ecological impacts should be viewed in a positive light.

\section{Conclusion}

Since ancient time, growing timber trees in farmland has been extensively practiced in Pakistan; it is now widely practiced in rural areas to fulfill the high demand for fuelwood, fodder and numerous other benefits. With the recognition of a greater role of tress in farmland in global climate change and forest degradation debate, the AF practice in Pakistan and its ecological impacts should be viewed in a positive light. With this perspective in mind, this study purpose to evaluate how farmer from the agricultural region of northern irrigated plain of Pakistan perceive and manage their AF land, which possesses numerous ecological benefits for the sustainability and functioning for agricultural landscape.

In general, this work has demonstrated the various factors influenced perception by combining both qualitative and quantitative methods, such as farmer age, education, and experience, type of AF system, origin of trees species, arrangement of tree planting, 
perceptions of the advantages and disadvantages of tree plantation. It was found that majority of farmers was middle age, acquired ordinary level education and experience of up to 6-20 years was more likely to adopt AF.

Of them, the majority of farmer's perceived that AF increases the greenery, understory regeneration, water retention, and soil fertility of the farmland. On average, farmers are more like to practicing agrosilvopastoral systems and growing exotic species on farms. These basic findings are consistent with many other research conducted on the ecological impact of AF. However, our regression results indicated promising novel finding that farmers who planted native species and practicing the agrisilvicultural system had a positive perception of the ecological impact on AF. Moreover, two demographic variables namely education level and year of experience had significant impacts in terms of specific kinds of (soil and greenery) knowledge and perceptions. Overall, the study found that low technical knowledge and inadequate research on improving the quality of native species have negative impacts on the effectiveness of management of AF in Pakistan

Although, the people in northern irrigated plain of central Punjab have huge potential for tree growing on farms, but owing to less factual information and awareness among farmers about benefits of AF needs a provision of information through extension services. The outcome of the study provides support and guidance for researchers, NGOs progressive farmers, local authorities and government policymakers to sufficiently understand the factors haltering or positively facilitating a more accurate, views and attitude of the local perceptions of ecological impacts derived from AF.

\section{Acknowledgements}

This work was funded by Project of economic Development Research Center of National Forestry and Grassland Administration "Research on investment and financing Policies for Natural Forest Restoration" (grant number JYCL-2020-00021).

\section{Conflicts of Interest}

The authors declare no conflicts of interest.

\section{References}

1. PAKISTAN ECONOMIC SURVEY. Climate change. Chapter 16- Ministry of Finance, Government of Pakistan, Islamabad, Pakistan. 245, 2018.

2. CENTER FOR INTERNATIONAL FORESTRY RESEARCH (CIFOR). The Underlying Causes of Forest Decline. CIFOR, Bogor, Indonesia. 6, 2000.

3. RAHMAN F., HAQ F., TABASSUM I., ULLAH I. Socioeconomic drivers of deforestation in Roghani Valley,
Hindu-Raj Mountains, Northern Pakistan. J Mt Sci, 11, 167, 2014.

4. O'SULLIVAN J.N. The social and environmental influences of population growth rate and demographic pressure deserve greater attention in ecological economics. Ecol. Econ, 172, 106648, 2020.

5. VIGNOLA R., HARVEY C.A., BAUTISTA-SOLIS P., AVELINO J., RAPIDEL B., DONATTI C., MARTINEZ R. Ecosystem based adaptation for smallholder farmers: definitions, opportunities and constraints. Agric Ecosyst Environ, 211, 126, 2015.

6. REGANOLD J.P., WACHTER J.M. Organic agriculture in the twenty-first century. Nat Plants, 2, 15221, 2016.

7. About Agroforestry- Available online: http://www. worldagroforestry.org/ (accessed on 12 Feb 2020).

8. TORQUEBIAU E.F. A renewed perspective on agroforestry concepts and classification. Comptes Rendus de l'Académie des Sciences - Series III - Sciences de la Vie, 323, 1009, 2000.

9. ABBAS F., HAMMAD H.M., FAHAD S., CERDA A., RIZWA M., FARHAD W., EHSAN S., BAKHAT H.F. Agroforestry: a sustainable environmental practice for carbon sequestration under the climate change scenarios-a review. Environ Sci Pollut Res Int, 24, 11177, 2017.

10. JOSE S. Agroforestry for ecosystem services and environmental benefits: an overview. Agroforest Syst. 76, 10, 2009.

11. DEV I., RAM A., BHASKAR S., CHATURVEDI O.P. Role of Agroforestry in current scenario, Scientific Publishers: Jodhpur, India, 9, 2018.

12. DURU M., THEROND O., MARTIN G., CLOUAIRE R.M., MAGNE M.A., JUSTES E., JOURNET E.P., AUBERTOT J.N., SAVARY S., BERGEZ J.E., PIERRE J. How to implement biodiversity based agriculture to enhance ecosystem services: a review. Agron. Sustain. Dev, 35, 1259, 2015.

13. FLEMING A., O'GRADY A.P., MENDHAM D., ENGLAND J., MITCHELL P., MORONI M. LYONS A. Understanding the values behind farmer perceptions of trees on farms to increase adoption of agroforestry in Australia. Agron. Sustain. Deve, 39, 9, 2019.

14. BOHN J.L., DIEMONT S.A.W., GIBBS J.P., STEHMAN S.V., VEGA J.M. Implications of Mayan agroforestry for biodiversity conservation in the Calakmul Biosphere Reserve, Mexico. Agroforest Syst, 88, 269, 2014.

15. CARSAN S., STROEBEL A., DAWSON I., KINDT R., MBOW C., MOWO J., JAMNADASS R. Can agroforestry option values improve the functioning of drivers of agricultural intensification in Africa?. Curr Opin Environ Sustain, 6, 35, 2014.

16. LIN B.B. Agroforestry management as an adaptive strategy against potential microclimate extremes in coffee agriculture. Agric. For. Meteo, 144, 85, 2007.

17. HASANUZZAMAN M., MAHMOOD H., SAROAR M. Diversity and preference of agricultural crops in the cropland agroforests of southwestern Bangladesh. Int $\mathrm{J}$ Agric Crop Sci. 7, 364, 2014.

18. KIYANI P., ANDOH J., LEE Y., LEE DK. Benefits and challenges of agroforestry adoption: a case of Musebeya sector, Nyamagabe District in southern province of Rwanda. Forest Science and Technology, 13, 174, 2017.

19. FAROOQ T.H., GAUTAM N.P., RASHID M.H.U., GILANI M.M., NEMIN W., NAWAZ M.F., ISLAM W., ZAINAB M., WU P. Contributions of agroforestry on socioeconomic conditions of farmers in central Punjab, 
Pakistan - a case study. Cerce. ‘ri Agro. 1̂n Mold, 51, 91, 2018.

20. ZUBAIR M., GARFORTH C. Farm level tree planting in Pakistan: the role of farmers' perceptions and attitudes. Agroforest. Syst, 66, 217, 2006.

21. MURTHY I.K., DUTTA S., VARGHESE V., JOSHI P. P., KUMAR P. Impact of Agroforestry Systems on Ecological and Socio-Economic Systems: A Review. Glob. J. of Sci. Fr. Res: Environ. Earth Sci, 16 (15), 1, 2016.

22. JALON S.G.D., BURGESS P.J., GRAVES A., MORENO G. How is agroforestry perceived in Europe? An assessment of positive and negative aspects by stakeholders. Agroforest. Syst, 92 (4), 829, 2018.

23. MAHMOOD M.I., ZUBAIR M. Farmer's Perception of and Factors Influencing Agroforestry Practices in the Indus River Basin, Pakistan. Smal-scal.For, https://doi. org/10.1007/s11842-020-09434-9, 2020.

24. BUYINZA J., NUBERG I.K., MUTHURI C.W., DENTON M.D. Psychological Factors Influencing Farmers' Intention to Adopt Agroforestry: A Structural Equation Modeling Approach. Sustain. For, 39, 854, 2020.

25. FESTINGER L. An Introduction to the Theories of Cognitive Dissonance-Stanford University Press: Stanford, CA, pp. 89, 1956.

26. SHACKLETON R.T., RICHARDSON D.M., SHACKLETON C.M., BENNETT B., CROWLEY S.L., DEHNEN-SCHMUTZ K., ESTÉVEZ R.A., FISCHER A., KUEFFER C., KULL C.A., MARCHANTE E., NOVOA A., POTGIETER L.J., VAAS J., VAZ A.S., LARSON B.M.H. Explaining people's perceptions of invasive alien species: a conceptual framework. J. Env. Manag, 229, 10, 2019.

27. SILESHI G.W., KUNTASHULA E., MATAKALA P., NKUNIKA P.O. Farmers' perceptions of tree mortality, pests and pest management practices in agroforestry in Malawi, Mozambique and Zambia. Agroforest Sys, 72 (2), 87, 2008.

28. SHARMIN A., RABBI S.A. Assessment of farmers' perception of agroforestry practices in Jhenaidah district of Bangladesh. J. Agri. Ecol.Res.Intern, 1, 10, 2016.

29. Agro-ecological zones of Pakistan. Available online: http://www.parc.gov.pk/index.php/en/component/content/ article/43-maps/19-agrimaps. (accessed on 1st February 2020).

30. BAIG M.B., BURGESS P.J., FIKE J.H. Agroforestry for healthy ecosystems: constraints, improvement strategies and extension in Pakistan. Agroforest Syst, https:/doi. org/10.1007/s10457-019-00467-4, 2020.

31. RAHIM S.M.A., HASNAIN S. Agroforestry trends in Punjab, Pakistan. Afr J Environ Sci Technol, 4, 639, 2010.

32. BALASUBRAMANIAN A. Ecosystem and its components. Centre for Advanced Studies in Earth Science: University of Mysore, India, 28, 2008.

33. The 2 Main Components of an Ecosystem- Available online: https://sciencing.com/2-main-componentsecosystem-2576.html. (accessed on 9th Mar 2020).

34. TREWEEK J. Ecological impact assessment. Impact Asses, 13 (3), 289, 1995.

35. KLEMES J.J. Assessing and Measuring Environmental Impact and Sustainability, Elsevier: Amsterdam, Netherlands, pp. 608, 2015.

36. NABUNYA M. Contribution of agroforestry practices to reducing farmers' vulnerability to climate variability in Rakai district, Uganda, Department of Forest Sciences: Technische Universität Dresden, Germany, 27, 2017.
37. ALVAREZ I.G., GALINDO M.P.V., VILLARDÓN M.P.G., ROSA M.R. Environmental Performance in Countries Worldwide: Determinant Factors and Multivariate Analysis. Sustain, 6, 7807, 2014.

38. BANYAL R., MUGLOO J.A., MUGAL A.H., DUTT V., ZAFFAR S.N. Perception of Farmers' Attitude and Knowledge towards the Agroforestry Sector in North Kashmir. J. Tree Sci, 34 (2), 35, 2015.

39. FRANCO D., FRANCO D., MANNINO I., ZANETTO G. The impact of agroforestry networks on scenic beauty estimation: The role of a landscape ecological network on a socio-cultural process. Lands. Urb. Plan, 62 (3), 119, 2003.

40. TORRALBA M., FAGERHOLM N., BURGESS P.J., MORENO G., PLIENINGER T. Do European agroforestry systems enhance biodiversity and ecosystem services? A meta-analysis, Agric. Ecosy. Envi, 230, 150, 2016.

41. ROJAS R.J., RUSSY S., ROCO L., MUÑOZ D.F., ENGLER A. Factors Affecting the Adoption of Agroforestry Practices: Insights from Silvopastoral Systems of Colombia. Fores, 11, 648, 2020.

42. GREENE W. Econometric analysis, Macmillan: New York, USA, 37, 2010

43. ISLAM M.A., MASOODI T.H., GANGOO S.A., SOFI P.A., BHAT G.M., WANI A.A., GATOO A.A., SINGH A., MALIK A.R. Perceptions, attitudes and preferences in agroforestry among rural societies of Kashmir, India. J. Appl. Natural Sci, 7, 976, 2015.

44. PHONDANI P.C., MAIKHURI R.K., RAWAT L.S., NEGI V.S. Assessing farmers' perception on criteria and indicators for sustainable management of indigenous agroforestry systems in Uttarakhand, India. Envi Sustain. Indic, 5, 100018, 2020

45. ANASTASE G.M., NAHAYO L. Impact Assessment of Agroforestry Practices on Community Socio-Economic Livelihoods in Rwanda. Inter.J. Envi. Agri. Resea, 6 (1), 59, 2020.

46. MUFUDZA P. Impact of income generating projects on rural livelihoods: The case of mwenezi fish conservation project, Zimbabwe. University of Limpopo: Mankweng, South Africa, pp. 72, 2016.

47. HAJDU F., ANSELL N., ROBSON E., BLERK L.V. CHIPETA L. Income generating activities as components of sustainable rural livelihoods for young southern Africans: AIDS and other constraints. The Geog J, 177, 251, 2010.

48. EUROPEAN COMMISSION. POVERTY AND SOCIAL EXCLUSION IN RURAL AREAS. European Commission: Brussels, Belgium, 67, 187, 2008.

49. COLE R.J. Social and environmental impacts of payments for environmental services for agroforestry on small scale farms in southern Costa Rica. Inter. J. of Sustain. Dev. World Eco, 17 (3), 208, 2010.

50. SINGH B.K., ORAON P.R., KUMAR A., KUMAR A. Impact of Agroforestry practices on livelihood improvement of the farmers of Lohardaga District Jharkhand. J. Pharm. Phyto, 1, 1957, 2018.

51. KLOPFENSTEIN N.B., RIETVELD W.J., CARMAN R.C., CLASON T.R., SHARROW S.H., GARRETT G., ANDERSON B. Silvopasture: An Agroforestry Practice. USDA Forest Service, National Agroforestry Center: Lincoln,USA, 1, 1997.

52. ALAM M.R., JAHIRUDDIN M.D. Agroforestry for sustainable forage and livestock production in a smallholding farming system. J. Anim. Feed Sci, 16 (2), 76, 2007. 
53. JOSE S., DOLLINGER J. Silvopasture: a sustainable livestock production system. Agroforest Syst, 93, 9, 2019.

54. DA'VILA-SOLARTE P., SANGINE'S-GARCI'A L., AMEZCUA T., SOLANO L. Productive performance and economic evaluation of sheep grazing on weeds in coffee plantations compared to pastures with or without supplementation. Agroforest Syst. https://doi.org/10.1007/ s10457-017-0165-7, 2019.

55. OKULLO J.B.L., OBUA J., KABOGGOZU J.R.S., ALUM J.R.W. Traditional agroforestry systems, tree uses and management in northern Uganda. Uganda J. Agri. Sci, 8, $5,2003$.

56. QUANDT A., NEUFELDT H., MCCABE J.T. The role of agroforestry in building livelihood resilience to floods and drought in semiarid Kenya. Ecol. Soci, 22, 10, 2017.

57. HANIF M.A., ROY R.M., BARI M.S., RAY P.C., RAHMAN M.S., HASAN M.F. Livelihood Improvements Through Agroforestry: Evidence from Northern Bangladesh. Small-Scale For, 17, 505, 2018.

58. ROLIM S.G., CHIARELLO A.G. Slow death of Atlantic forest trees in cocoa agroforestry in southeastern Brazil. Biodivers. Conserv, 13: 2679, 2004.

59. SAGASTUY M., KRAUSE T. Agroforestry as a Biodiversity Conservation Tool in the Atlantic Forest? Motivations and Limitations for Small-Scale Farmers to Implement Agroforestry Systems in North-Eastern Brazil. Sustain, 11, 6932, 2019.

60. AMARE Z.Y., AYOADE J.O., ADELEKAN I.O., ZELEKE M.T. Barriers to and determinants of the choice of crop management strategies to combat climate change in Dejen District, Nile Basin of Ethiopia. Agric.food.Secu, 7, 37, 2018.

61. PINHO R.C., MILLER R.P., ALFAIA S.S. Agroforestry and the Improvement of Soil Fertility: A View from Amazonia. Appl. Envi, Soil Sci, 1, 11, 2012.

62. Agroforestry can help to reverse the trend of global soil degradation. Available online: https://agroforestrynetwork. org/world-soil-day-agroforestry-can-help-to-reverse-thetrend-of-global-soil-degradation. (accessed on $3^{\text {th }}$ April 2020), 2018.

63. TESEMMA A.B. A Participatory Agroforestry Approach for Soil and Water Conservation in Ethiopia: Wageningen Agricultural University, Netherlands, 53, 1997.

64. ROOSE E., NDAYIZIGIYE F. Agroforestry, water and soil fertility management to fight erosion in tropical mountains of Rwanda. Soil Technology, 11 (1), 109, 1997.

65. WOLDE Z. The role of agroforestry in soil and water conservation. Lampart Acadamic Publishing: Saarbrücken, Germany, 27, 2015.
66. PANDEY R. Groundwater Irrigation in Punjab, Some Issues and a Way Forward: National Institute of Public Finance and Policy: New Delhi, India, 97, 2016.

67. Paddy, tube wells and depleting groundwater: Why Punjab's water resources are under strain. Available online:https://www.thehindu.com/ news/national/ otherstates/paddy-tube-wells-and-depleting-groundwater/ article29112950.ece (accessed on $15^{\text {th }}$ April 2020), 2019.

68. SCHROTH G., KRAUSS U., GASPAROTTO L., AGUILAR J.A.D., VOHLAND K. Pests and diseases in agroforestry systems of the humid tropics. Agroforest Syst, 50, 199, 2000.

69. JONSSON M. Agroforestry practices results in less pests, plant diseases and weeds Swedish University of Agricultural Sciences Uppsala, Sweden, 35, 2015.

70. LIU H., LUO X. Understanding Farmers' Perceptions and Behaviors towards Farmland Quality Change in Northeast China: A Structural Equation Modeling Approach. Sustain, 10, 3345, 2018.

71. FOGUESATTO C.R., MACHADO J.A.D. What shapes farmers' perception of climate change? A case study of southern Brazil. Envi. Dev. Sust. https://doi.org/10.1007/ s10668-020-00634-z, 2020.

72. SAHA S., SHARMIN A., BISWAS R., ASHADUZZAMAN M. Farmers' Perception and Adoption of Agroforestry Practices in Faridpur District of Bangladesh. Int. J. Envi. Agri Biotech, 3 (6), 1987, 2018.

73. SHARMIN A., RABBI S.A. Assessment of farmers' perception of agroforestry practices in Jhenaidah District of Bangladesh. J Agric Ecol Res Int, 6, 10, 2016.

74. PETTIT R. E. Organic matter, humus, humate, humic acid, fulvic acid and humin: their importance in soil fertility and plant health. CTI Resear. 1, 17, 2004.

75. RAO M. R., NAIR P.K., ONG C. K. Biophysical interactions in tropical agroforestry systems. Agroforest. Syst, 38 (1-3), 3, 1997.

76. KAGAWA A., SACK L., DUARTE K., JAMES S. Hawaiian native forest conserves water relative to timber plantation: Species and stand traits influence water use. Ecol. Appli, 19 (6), 1429, 2009.

77. CARUSO C.M. Competition for Pollination Influences Selection on Floral Traits of Ipomopsis aggregate. Int, J.Org. Evolu, 1546, 2000.

78. BROWN B.J., MITCHELL R.J., GRAHAM S.A. Competition for pollination between an invasive species (purple loosestrife) and a native congener. Ecol, 83, 2328, 2020.

79. BARBETA A., PEÑUELAS JR. Relative contribution of groundwater to plant transpiration estimated with stable isotopes. Sci. report, 7, 10580, 2017. 